\title{
HIV/AIDS treatment failure and associated factors in Ethiopia: meta-analysis
}

\author{
Aklilu Endalamaw ${ }^{1 *}$ (D), Mengistu Mekonnen ${ }^{2}$, Demeke Geremew ${ }^{3}$, Fikadu Ambaw Yehualashet ${ }^{4}$, Hiwot Tesera ${ }^{5}$ and \\ Tesfa Dejenie Habtewold ${ }^{6}$
}

\begin{abstract}
Background: The national burden of human immunodeficiency virus treatment failure and associated factors in the Ethiopian context is required to provide evidence towards a renewed ambitious future goal.

Methods: We accessed Ethiopian Universities' online repository library, Google Scholar, PubMed, Web of Science, and Scopus to get the research articles. We run I-squared statistics to see heterogeneity. Publication bias was checked by using Egger's regression test. The pooled prevalence was estimated using the DerSimonian-Laird random-effects model. We employed the sensitivity analysis to see the presence of outlier result in the included studies.

Results: The overall human immunodeficiency treatment failure was 15.9\% (95\% confidence interval: 11.6-20.1\%). Using immunological, virological, and clinical definition, human immunodeficiency treatment failure was 10.2\% (95\% confidence interval: 6.9-13.6\%), 5.6\% (95\% confidence interval: 2.9-8.3\%), and 6.3\% (95\% confidence interval: 4.6-8.0\%), respectively. The pooled effects of World Health Organization clinical stage III/IV (Adjusted Odd Ratio = 1.9; 95\% Cl: 1.32.6), presence of opportunistic infections (Adjusted Odd Ratio $=1.8 ; 95 \% \mathrm{Cl}: 1.2-2.4$ ), and poor adherence to highly active antiretroviral therapy (Adjusted Odd Ratio $=8.1 ; 95 \% \mathrm{Cl}$ : 4.3-11.8) on HIV treatment failure were estimated.

Conclusions: Human immunodeficiency virus treatment failure in Ethiopia found to be high. Being on advanced clinical stage, presence of opportunistic infections, and poor adherence to highly active antiretroviral therapy were the contributing factors of human immunodeficiency virus treatment failure. Human immunodeficiency virus intervention programs need to address the specified contributing factors of human immunodeficiency virus treatment failure. Behavioral intervention to prevent treatment interruption is required to sustain human immunodeficiency virus treatment adherence.
\end{abstract}

Protocol registration: It has been registered in the PROSPERO database with a registration number of CRD42018100254.

Keywords: HAART, HIV, Failure, Treatment, Ethiopia

\section{Background}

Globally, there were approximately 37.9 million Human Immunodeficiency Virus (HIV) infected people and around 770,000 people died from AIDS-related illnesses worldwide in 2018. In this year, there were 20.6 million people with HIV in eastern and southern Africa, and 5.0 million in western and central Africa [1]. In Ethiopia, 690,000 people were living with HIV in 2018 [2].

\footnotetext{
* Correspondence: yaklilu12@gmail.com

${ }^{1}$ Department of Pediatrics and Child Health Nursing, School of Health

Sciences, College of Medicine and Health Sciences, Bahir Dar University, P.O.

Box 196, Bahir Dar, Ethiopia

Full list of author information is available at the end of the article
}

In 2018, 23.3 million people with HIV were accessing antiretroviral therapy (ART) worldwide [1]. In the same year, $65 \%$ of people living with HIV were on treatment in Ethiopia [2]. A review of the HIV situation in Addis Ababa Ethiopia revealed that weak monitoring of the quality of interventions, limited linkage of HIV-positive clients, lost to follow-up, financial shortage, limited man-power, and gaps in the use of program data were the challenges of HIV/AIDS treatment [3].

The risk of death due to HIV has been decreased after the era of highly active antiretroviral therapy (HAART) [4]. Evidence has shown that an individual on HAART with an undetectable viral load, absence of an advanced 
clinical finding, and high CD4 count are less likely to transmit HIV to another person $[5,6]$. However, the risk of HIV transmission is high due to treatment failure. Treatment failure can be a virological, immunological, or clinical failure [7]. Virological failure is a plasma viral load above 1000 copies/ $\mathrm{ml}$ based on two consecutive viral load measurements after 3 months with adherence support [7]. Immunological failure is when the CD4 count falls to the baseline (or below) or persistent CD4 levels below 100 cells/mm3 for adult and adolescent or below 200 cells/ $\mathrm{mm} 3$ in younger than 5 years. Clinical failure is defined as the occurrence or recurrence of advanced WHO clinical stage after 6 months of therapy [7].

Globally, UNAIDS planned to have $90 \%$ of people on HAART are virally suppressed by 2030 and as a result, HIV treatment failure would be prevented [8]. Despite this ambitious goal, as of a systematic analysis of national HIV treatment cascades of 69 countries by 2016, viral suppression was between 7\% in China and 68\% in Switzerland [9]. It can be prevented through the implementation of globally recommended strategies. For instance, improving HAART adherence, taking medication based on the appropriate prescription, prevent drug-drug interaction, increasing knowledge and attitudes of patients towards HAART, timely initiation of HAART, prevention and control of opportunistic infections, and implementation of effective food and nutrition policy.

A higher viral load may lead to HIV treatment failure, which is becoming a threat of different African countries, like in Burkina Faso (6.4\%) [10], Ghana (15.7\%) [11], and Tanzania (14.9\%) [12]. In Ethiopia, virological, immunological, and clinical failure is found in the range between $1.3 \%$ [13] to $11.5 \%$ [14], $2.1 \%$ [15] to $21 \%$ [16], and $3.1 \%$ [17] to $12.3 \%$ [18], respectively.

With these variations of reports, there is no pooled representative national data in Ethiopia. In order to provide evidence towards a renewed ambitious future goal, it is now critical to reflect the pooled burden of HIV treatment failure in the Ethiopian context. The objective of this study was first, to estimate the national burden of HIV treatment failure and secondly, to review contextual factors of HIV treatment failure using globally accepted key performance indicators as a framework. Thus, this information will be helpful for healthcare professionals and further helps to enable the country to sustain successes and improve weaknesses towards the goal of ending AIDS strategy.

\section{Methods}

\section{Reporting}

It is reported based on the Preferred Reporting Items for Systematic Reviews and Meta-analyses (PRISMA) guideline [19] (supplementary file-research checklist). Its protocol is registered in the Prospero database with a registration number of CRD42018100254.

\section{Search strategy}

PubMed, Web of Science, Scopus, and Google Scholar databases were used to get the research articles. The search strategy made in PubMed was: [("Human Immunodeficiency virus"[MeSH Terms] OR HIV OR AIDS OR "Acquired Immunodeficiency syndrome" AND ("antiretroviral therapy" [MeSH Terms] OR "highly antiretroviral therapy" OR HAART OR ART OR "ARV Therapy" OR "antiretroviral therapy") AND (outcome OR "treatment failure" OR failure OR "virological failure" OR "immunological failure" OR "Clinical failure") AND (Ethiopia)]. The search done in PubMed through search terms was 03/10/2018. In addition, Ethiopian Universities' (University of Gondar and Addis Ababa University) online repository library were searched. Endnote 7 reference manager software was used to manage duplicated references and for citation in the text.

\section{Inclusion and exclusion criteria}

Those articles included in this meta-analysis were: [1] cohort, case-control, and cross-sectional studies, [2] studies that reported the prevalence and/ or AOR (adjusted odds ratio) of associated factors of overall HAART treatment, immunological, clinical, and virological failure, [3] studies conducted in Ethiopia, and [4] studies published in English.

Studies without full-text access, qualitative studies, and conference proceeding without full-text reports were excluded.

\section{Outcome measurement}

According to WHO [7], HIV treatment failure could be a clinical, immunological, and virological failure.

The prevalence of failure was ascertained by dividing the participants with the outcome of interests to the overall study participants multiplied by 100 .

\section{Quality assessment}

Two authors assessed the quality of the articles based on the Newcastle-Ottawa Scale quality assessment tool for cross-sectional, case-control, and cohort studies [20]. The criteria for cross-sectional studies have three sections, in which the first section focused on selection and graded by four stars, the second section dedicated with the comparability of the study and graded by two stars, and the third section emphasized on the outcome and graded by three stars. The criteria for case-control studies were: 1 ) selection evaluated by four stars, 2) comparability assessed by two stars, and 3) exposure graded by four stars. The criteria for cohort studies were: 1) selection graded by six stars, 2) comparability graded by two stars, and 3) outcome graded by five stars. Whenever disagreement happened between the two quality assessors, the procedure would be repeated and further solved with the involvement of the third reviewer. Cross-sectional, case-control, and cohort studies scored 6 and/or above, 7 and/or above, 
and 9 and/or above quality assessment criteria were included respectively.

\section{Data extraction process}

Two authors extracted the required data. The first author and year of publication, sample size, an outcome of interest, study design, study population, the geographical location of the study, fund, and response rate were collected.

\section{Data synthesis and statistical analysis}

STATA 14 (Stata Corp, College Station, TX, USA) statistical software was used for meta-analysis. Publication bias assessed by the funnel plot and more objectively by Egger's regression test. I-squared statistics was used to check the heterogeneity of the studies. The DerSimonianLaird random-effects model was employed to estimate the overall prevalence. Subgroup analysis based on the geographical location of the study, type of treatment failure, study population by age, and study design was conducted to see the variation in outcomes. The sensitivity analysis was also employed to see whether the outlier result found in the included studies.

\section{Results}

\section{Search results}

A total of 873 articles were found from PubMed $(n=187)$, Google Scholar $(n=134)$, Web of Science $(n=21)$, Scopus $(\mathrm{n}=13)$, and Ethiopian Universities' online repository library (University of Gondar and Addis Ababa University) $(n=33)$. A total of 331 articles have remained after duplicate studies were removed. Then, 302 articles were removed based on the unmatched title and abstracts. Finally, 18 articles were included (Fig. 1).

\section{Characteristics of studies}

Studies found through databases search were done between 2005 and 2016. Eight of the studies were conducted in the Amhara region, whereas five in Addis Ababa [13, 21-24], three in Oromia [18, 25, 26], one in Tigray [14], and one in SNNPR [27]. Three studies were done by case-control study design [24, 28, 29], four studies by cross-sectional $[14,30-32]$, and eleven by cohort study design $[13,15-18$, 21-23, 25-27]. Ten studies were done on adult population $[13,16,17,21,23-25,28,29,32]$, six on children $[15,18$, $22,26,27,31]$, and two on all age group [14, 30] (Table 1).

\section{Publication bias}

The funnel plot for HIV treatment failure is shown below (Fig. 2). Egger's regression test of the $p$-value for overall HIV treatment failure is 0.226 .

\section{Meta-analysis \\ HIV treatment failure based on the definition of HAART \\ failure}

A total of 4738 participants in nine studies were used to estimate the pooled prevalence of HIV treatment failure

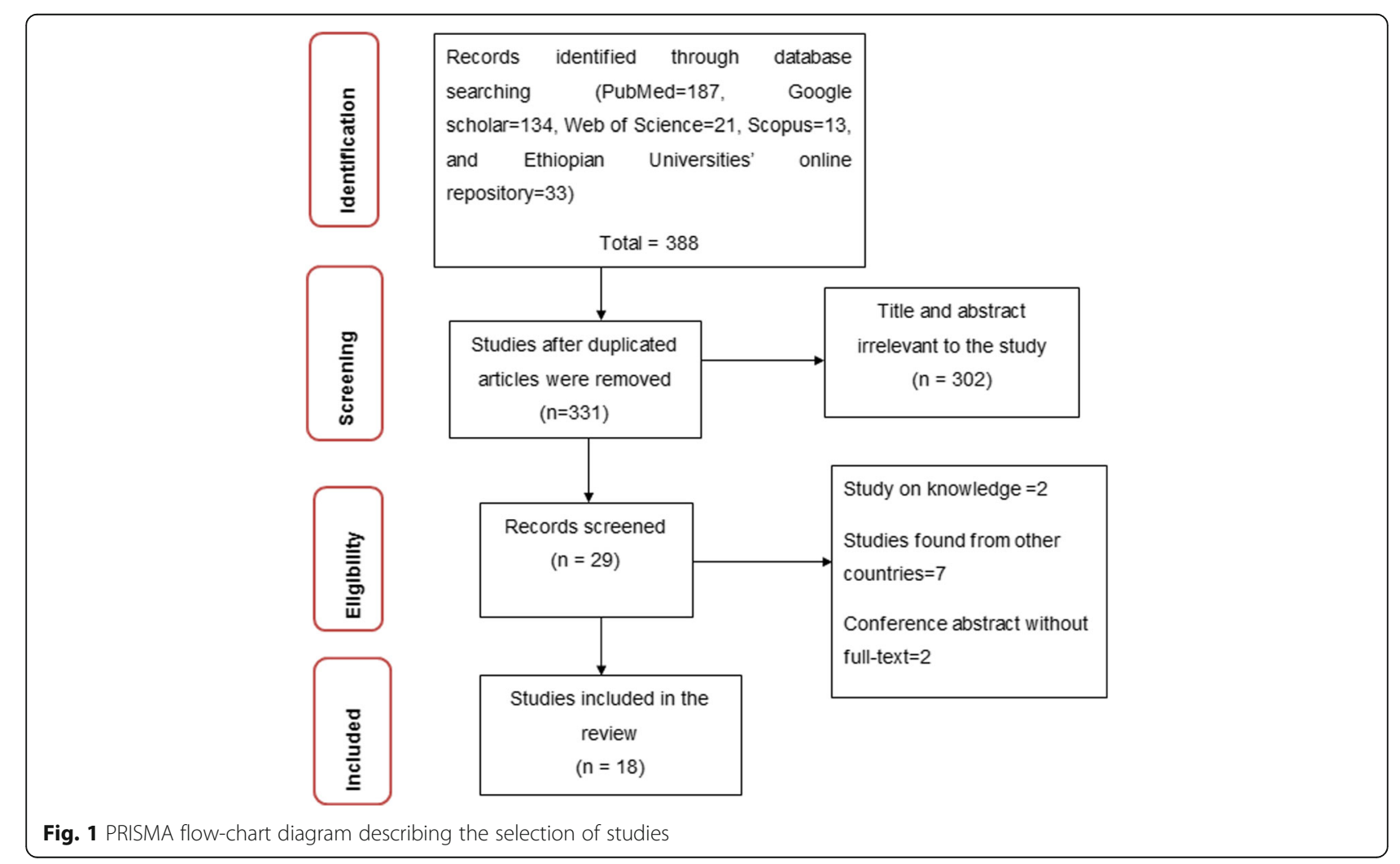


based on the definition of HAART failure. The pooled prevalence of HIV treatment failure was 15.9\% (95\% CI: 11.6-20.1\%) (Fig. 3).

Immunological and Virological definition of HIV treatment failure A total of 5899 study participants in 13 studies were involved to determine HIV treatment failure based on the immunological definition. Of which, 10.2\% (95\% CI: 6.9-13.6\%) developed immunological failure. Regarding virological failure, the pooled prevalence from six studies with a total of 2406 participants was 5.6\% (95\% CI: 2.9-8.3\%) (Fig. 4).

\section{Clinical definition of HIV treatment failure}

A total of 4497 study participants in 9 studies were found to estimate the clinical failure, in which the pooled prevalence was 6.3\% (95\% CI: 4.6-8.0\%) (Fig. 5).

\section{Subgroup analysis}

Subgroup analysis was employed based on region, age of the study participants, and study design. Lower prevalence of HIV treatment failure based on the definition of HAART, immunological, and virological failure was 13.7\% in Amhara, $6.5 \%$ in Tigray, and 1.5\% in Addis Ababa, respectively (Table 2).

\section{Sensitivity analysis}

In the sensitivity analysis, the overall HIV treatment failure based on the definition of HAART failure was observed high (17.3\%) and low (15.2\%) when Ayalew $M B$ et al 2016 and Sisay $C$ et al/2017 was omitted respectively. The minimum pooled prevalence of HIV treatment failure based on immunological definition (9.3\%), virological definition (4.4\%), and clinical definition (5.5\%)

Table 1 Characteristic of included studies in systematic review and meta-analysis

\begin{tabular}{|c|c|c|c|c|c|c|c|}
\hline First Author/Year & $\begin{array}{l}\text { Study } \\
\text { period }\end{array}$ & Region & Study design & $\begin{array}{l}\text { Study } \\
\text { population }\end{array}$ & $\begin{array}{l}\text { Sample } \\
\text { size }\end{array}$ & $\begin{array}{l}\text { Response } \\
\text { rate }\end{array}$ & Source of fund \\
\hline Teshome W/2015 [28] & $\begin{array}{l}2007- \\
2009\end{array}$ & $\begin{array}{l}\text { Addis } \\
\text { Ababa }\end{array}$ & $\begin{array}{l}\text { Retrospective } \\
\text { cohort }\end{array}$ & Adult & 293 & $100 \%$ & Not reported \\
\hline $\begin{array}{l}\text { Bokretsion BG et al./ } \\
2017 \text { [23] }\end{array}$ & 2016 & Amhara & Cross-sectional & $\begin{array}{l}\text { All age } \\
\text { group }\end{array}$ & 421 & $100 \%$ & $\begin{array}{l}\text { Bahirdar University and Ethiopian public } \\
\text { health institute }\end{array}$ \\
\hline Yassin S/2017 [20] & $\begin{array}{l}2006- \\
2015\end{array}$ & Oromia & $\begin{array}{l}\text { Retrospective } \\
\text { cohort }\end{array}$ & children & 269 & $86.8 \%$ & Not reported \\
\hline Zeleke A/2016 [24] & $\begin{array}{l}2005- \\
2013\end{array}$ & Amhara & $\begin{array}{l}\text { Retrospective } \\
\text { cohort }\end{array}$ & children & 225 & $100 \%$ & Not reported \\
\hline Yimer YT/2015 [15] & $\begin{array}{l}2009- \\
2013\end{array}$ & $\begin{array}{l}\text { Addis } \\
\text { Ababa }\end{array}$ & $\begin{array}{l}\text { Retrospective } \\
\text { cohort }\end{array}$ & Adult & 525 & $100 \%$ & Not reported \\
\hline $\begin{array}{l}\text { Bacha T et al./2012 } \\
{[29]}\end{array}$ & $\begin{array}{l}2005- \\
2011\end{array}$ & $\begin{array}{l}\text { Addis } \\
\text { Ababa }\end{array}$ & $\begin{array}{l}\text { Retrospective } \\
\text { cohort }\end{array}$ & children & 1186 & $100 \%$ & Not reported \\
\hline $\begin{array}{l}\text { Ayalew MB et al./2016 } \\
{[25]}\end{array}$ & $\begin{array}{l}2011- \\
2015\end{array}$ & Amhara & $\begin{array}{l}\text { Retrospective } \\
\text { study }\end{array}$ & Adult & 340 & $100 \%$ & University of Gondar, Ethiopia \\
\hline $\begin{array}{l}\text { Sisay MM et al./2018 } \\
{[17]}\end{array}$ & $\begin{array}{l}2010- \\
2016\end{array}$ & Amhara & $\begin{array}{l}\text { Retrospective } \\
\text { cohort }\end{array}$ & children & 824 & $81.9 \%$ & University of Gondar, Ethiopia \\
\hline $\begin{array}{l}\text { Tsegaye AT et al./2016 } \\
\text { [19] }\end{array}$ & $\begin{array}{l}2006- \\
2014\end{array}$ & Amhara & $\begin{array}{l}\text { Retrospective } \\
\text { cohort }\end{array}$ & Adult & 356 & $100 \%$ & University of Gondar,Ethiopia \\
\hline $\begin{array}{l}\text { Hailu GG et al./2017 } \\
\text { [16] }\end{array}$ & $\begin{array}{l}2008- \\
2016\end{array}$ & Tigray & Cross-sectional & $\begin{array}{l}\text { All age } \\
\text { group }\end{array}$ & 260 & $100 \%$ & Mekelle Univesity, Ethiopia \\
\hline $\begin{array}{l}\text { Yayehirad AM et al./ } \\
2013 \text { [18] }\end{array}$ & $\begin{array}{l}2007- \\
2008\end{array}$ & Amhara & $\begin{array}{l}\text { Retrospective } \\
\text { cohort }\end{array}$ & Adult & 509 & $100 \%$ & University of Gondar,Ethiopia \\
\hline $\begin{array}{l}\text { Abdissa A et al./2014 } \\
\text { [32] }\end{array}$ & $\begin{array}{l}2010- \\
2012\end{array}$ & Oromia & $\begin{array}{l}\text { Prospective } \\
\text { cohort }\end{array}$ & Adult & 265 & $100 \%$ & $\begin{array}{l}\text { Danish International Development Agency } \\
\text { (DANIDA) }\end{array}$ \\
\hline $\begin{array}{l}\text { Tadesse BT et al. /2017 } \\
\text { [33] }\end{array}$ & $\begin{array}{l}2015- \\
2016\end{array}$ & SNNPR & cohort & children & 628 & $100 \%$ & Hawassa University, Ethiopia \\
\hline $\begin{array}{l}\text { Workneh N et al./2009 } \\
\text { [34] }\end{array}$ & $\begin{array}{l}2005- \\
2008\end{array}$ & Oromia & $\begin{array}{l}\text { Retrospective } \\
\text { cohort }\end{array}$ & children & 96 & $100 \%$ & Jimma University, Ethiopia \\
\hline Sisay C et al./2017 [30] & $\begin{array}{l}2011- \\
2016\end{array}$ & $\begin{array}{l}\text { Addis } \\
\text { Ababa }\end{array}$ & $\begin{array}{l}\text { Retrospective } \\
\text { cohort }\end{array}$ & Adult & 595 & $100 \%$ & Ethiopian public health institute \\
\hline $\begin{array}{l}\text { Babo YD et al./2017 } \\
{[26]}\end{array}$ & 2014 & Amhara & Case-control & Adult & 304 & $100 \%$ & USAID \\
\hline Bayu B et al./2017 [27] & 2015 & Amhara & Case-control & Adult & 306 & $100 \%$ & Not reported \\
\hline Getnet Y /2014 [31] & $\begin{array}{l}2005- \\
2011\end{array}$ & $\begin{array}{l}\text { Addis } \\
\text { Ababa }\end{array}$ & Case-control & Adult & 309 & $100 \%$ & Jimma University, Ethiopia \\
\hline
\end{tabular}




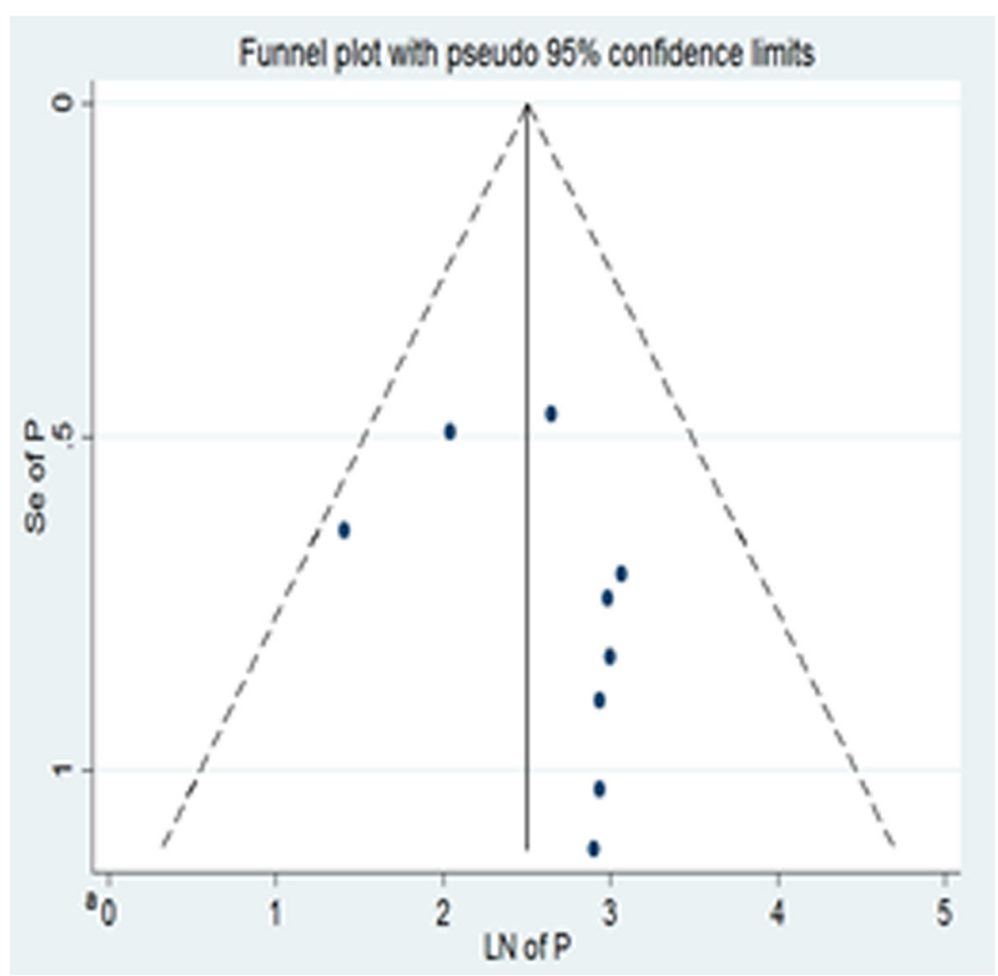

Fig. 2 Funnel plot, in which the vertical line indicates the effect size whereas the diagonal line indicates the precision of individual studies with 95\% confidence limit

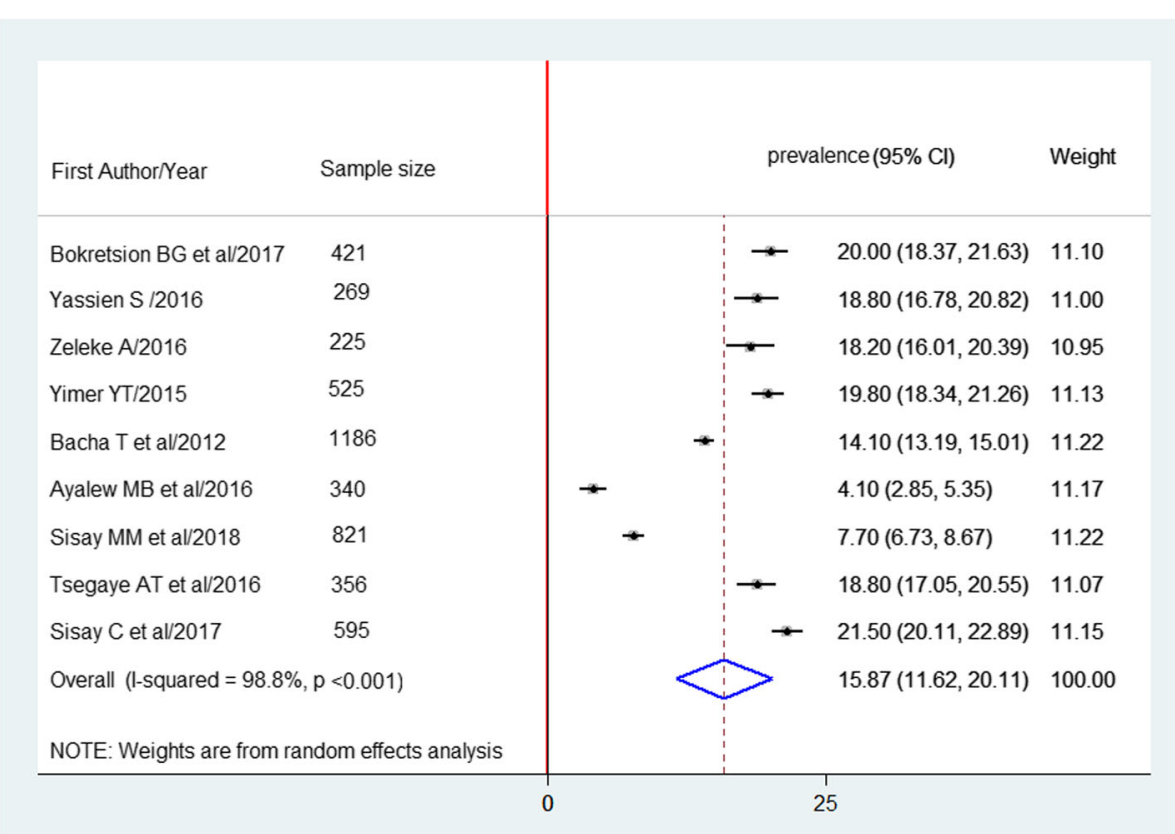

Fig. 3 Forest plot of the prevalence of HAART failure in Ethiopia and its $95 \% \mathrm{Cl}$, the midpoint of each line illustrates the prevalence rate estimated in each study. The diamond shows pooled prevalence 


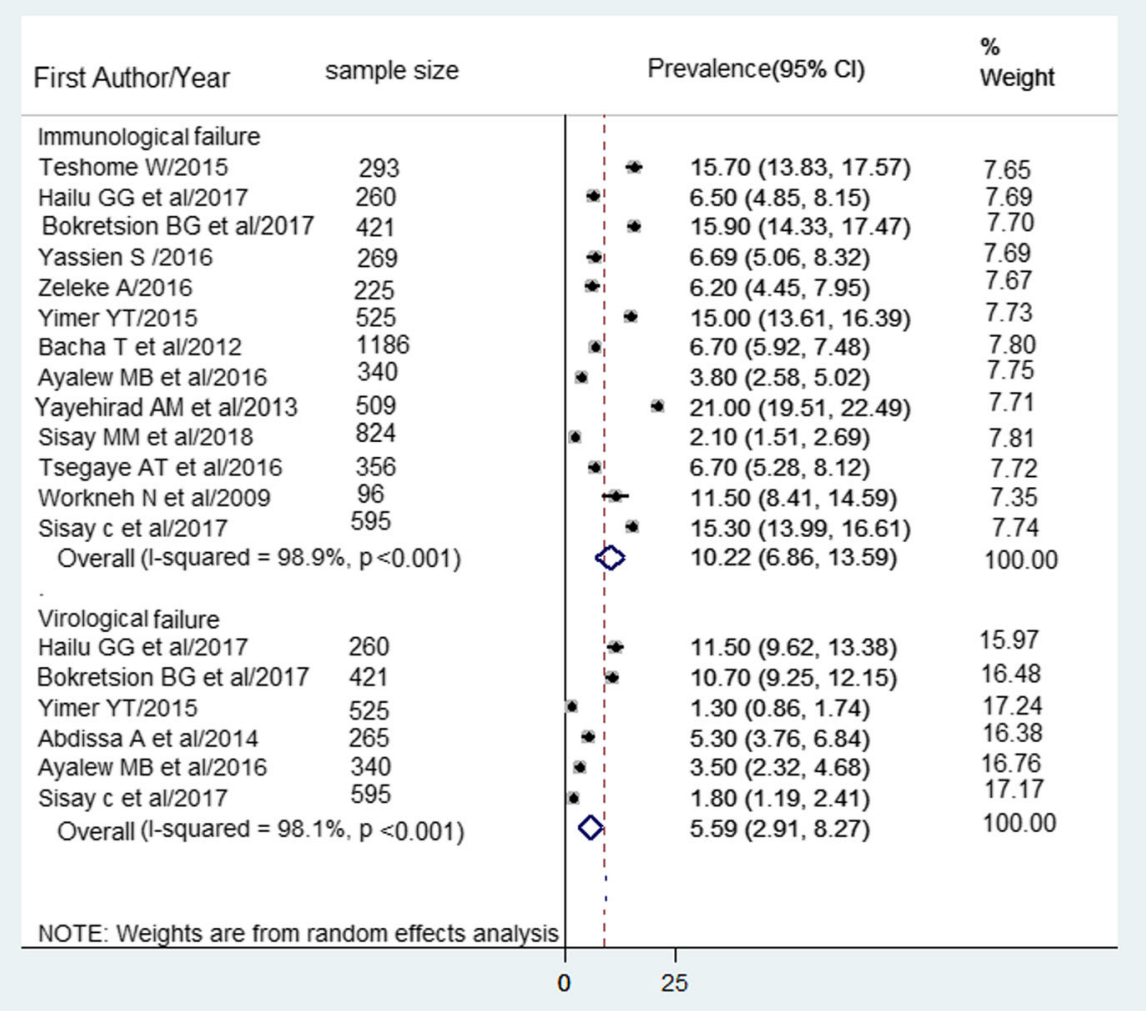

Fig. 4 Forest plot of the prevalence of immunological and virological failure in Ethiopia and its $95 \% \mathrm{Cl}$, the midpoint of each line illustrates the prevalence rate estimated in each study. The diamond shows pooled prevalence

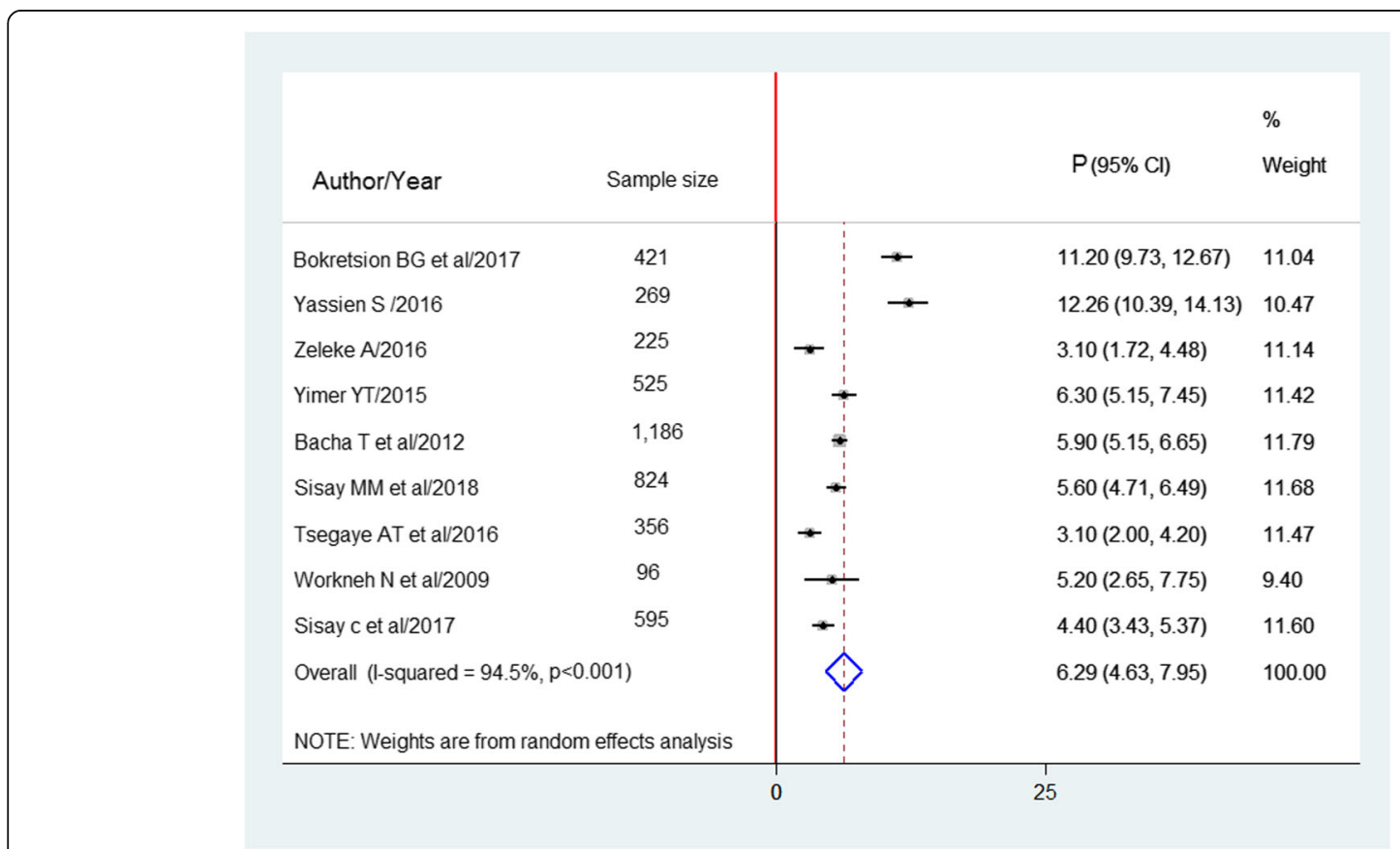

Fig. 5 Forest plot of the prevalence of clinical failure in Ethiopia and its $95 \% \mathrm{Cl}$, the midpoint of each line illustrates the prevalence rate estimated in each study. The diamond shows pooled prevalence 
Table 2 Subgroup analysis of the prevalence (p) of HIV treatment failure based on overall HAART, immunological, virological, and clinical definition by region, age, and study design in Ethiopia

\begin{tabular}{|c|c|c|c|c|}
\hline Subgroup analysis & Overall HAART failure P $(95 \% \mathrm{Cl})$ & Immunological failure P $(95 \% \mathrm{Cl})$ & Virological failure P $(95 \% \mathrm{Cl})$ & Clinical failure $\mathrm{P}(95 \% \mathrm{CI})$ \\
\hline \multicolumn{5}{|l|}{ By Region } \\
\hline Amhara & $13.7(7.3-20.2)$ & $9.3(3.3-15.2)$ & $7.1(0.03-14.1)$ & $5.7(2.6-8.9)$ \\
\hline Oromia & $18.8(16.8-20.8)$ & $8.9(4.2-13.6)$ & $5.3(3.8-6.8)$ & $8.8(1.9-15.7)$ \\
\hline Addis Ababa & $18.4(13.6-23.3)$ & $13.2(7.9-18.4)$ & $1.5(1.0-2.0)$ & $5.5(4.4-6.6)$ \\
\hline Tigray & - & $6.5(4.9-8.2)$ & $11.5(9.6-13.4)$ & - \\
\hline \multicolumn{5}{|c|}{ By age of participants } \\
\hline All age group & $20.0(18.4-21.6)$ & $11.2(2.0-20.4)$ & $11.0(9.9-12.2)$ & $11.2(9.7-12.7)$ \\
\hline Adult & $16.0(7.4-24.7)$ & $12.9(7.6-18.3)$ & $2.8(1.5-4.1)$ & $4.6(2.9-6.3)$ \\
\hline Children & $14.6(9.7-19.6)$ & $6.4(3.6-9.3)$ & - & $6.4(4.2-8.5)$ \\
\hline \multicolumn{5}{|l|}{ By Study design } \\
\hline Cross-sectional & $14.1(3.0-25.2)$ & $8.1(2.7-13.5)$ & $8.5(3.2-13.9)$ & $7.2(0.8-15.8)$ \\
\hline Cohort & $16.8(12.2-21.37)$ & $11.2(6.8-15.6)$ & $2.6(1.1-4.0)$ & $6.0(4.5-7.5)$ \\
\hline Combined & $15.8(11.6-20.1)$ & $10.2(6.9-13.6)$ & $5.6(2.9-8.3)$ & $6.3(4.6-8.0)$ \\
\hline
\end{tabular}

_ denotes no estimation due to lack of original studies

when Yayehirad AM et al/2013, Hailu GG et al /2015, and Yassin S /2016 omitted, respectively. And the maximum pooled prevalence of HIV treatment failure based on immunological definition (10.8\%) and virological failure (6.5\%) Ayalew $M B$ et al/2016 and Yimer YT/2015 was dropped from the analysis, respectively (Table 3).

\section{Associated factors of HIV treatment failure}

HIV treatment failure is attributed to socio-demographic, clinical, drug, and health system-related factors.

\section{Socio-demographic factors}

Based on a single study report, children's age between 6 and 9 years $(\mathrm{AOR}=0.26$; $95 \% \mathrm{CI}: 0.09-0.72$ ) was protective towards HIV treatment failure as compared to 10-15 years old children [18]. Another study showed children less than 3 years old were high risk $(\mathrm{AHR}=1.85 ; 95 \% \mathrm{CI}$ : 1.24-2.76) for HIV treatment failure as compared to 5-15 years old children [22].

One study which was done on the adult population [29] showed that those aged $<35$ years were high risk

Table 3 The prevalence $(p)$ of HIV treatment failure based on HAART failure, immunological, virological, and clinical definition when the study omitted in Ethiopia

\begin{tabular}{lllll}
\hline Study omitted & HAART failure P $(95 \% \mathrm{Cl})$ & Immunological failure P $(95 \% \mathrm{Cl})$ & Virological failure P $(95 \% \mathrm{Cl}$ & $\mathrm{Clinical}$ failure $\mathrm{P}(95 \% \mathrm{Cl})$ \\
\hline Bokretsion BG et al./2017 & $15.3(10.8-19.9)$ & $9.7(6.3-13.2)$ & $4.5(2.3-6.7)$ & $5.6(4.2-7.1)$ \\
Yassin S /2017 & $15.5(10.9-20.1)$ & $10.5(6.9-14.1)$ & - & $5.5(4.1-7.1)$ \\
Zeleke A/2016 & $15.6(11.0-20.2)$ & $10.6(7.0-14.1)$ & - & $6.7(4.9-8.4)$ \\
Yimer YT/2015 & $15.4(10.8-19.9)$ & $9.8(6.4-13.3)$ & - & $6.3(4.4-8.2)$ \\
Bacha T et al./2012 & $16.1(10.9-21.3)$ & $10.5(6.6-14.4)$ & $6.0(2.9-9.2)$ & $6.4(4.3-8.4)$ \\
Ayalew MB et al./2016 & $17.3(13.5-21.2)$ & $10.8(7.1-14.4)$ & - \\
Sisay MM et al./2018 & $16.9(12.6-21.2)$ & $10.9(7.7-14.1)$ & - & $6.4(4.4-8.4)$ \\
Tsegaye AT et al./2016 & $15.5(10.9-20.1)$ & $10.5(6.9-14.1)$ & - & $6.7(5.0-8.4)$ \\
Teshome W/2015 & - & $9.8(6.3-13.2)$ & $4.4(2.0-6.9)$ & - \\
Hailu GG et al./2015 & - & $10.5(6.9-14.1)$ & - & - \\
Yayehirad AM et al./2013 & - & $9.3(6.3-12.4)$ & - & $6.4(4.6-8.2)$ \\
Workneh N et al./2009 & - & $10.1(6.6-13.6)$ & $6.4(2.4-10.4)$ & $6.5(4.7-8.4)$ \\
Sisay C et al./2017 & $15.2(10.8-19.5)$ & $9.8(6.4-13.2)$ & $5.6(2.7-8.6)$ & - \\
Abdissa A et al./2014 & - & - & $5.6(2.9-8.3)$ & $6.3(4.6-7.9)$ \\
Combined & $15.8(11.6-20.1)$ & $10.2(6.8-13.6)$ & &
\end{tabular}

_ denotes no estimation due to lack of original studies 
$(\mathrm{AOR}=2.5 ; 95 \%$ CI: $1.3-4.8)$ to develop HIV treatment failure as compared to their counterparts.

From a single study, male adult patients $(\mathrm{AOR}=4.6$; 95\% CI: 1.7-12.3) [14], and patients in the formal educational level (AOR $=5.15 ; 95 \%$ CI: $1.5-17.3)$ [28] were at higher risk for HIV treatment failure.

Babo YD et al/2017 (AOR $=4.9 ; 95 \%$ CI: $1.5-16)$ and Yayehirad MA et al/2013 (AOR $=1.7 ; 95 \%$ CI: 1.1-2.7) $[16,28]$ found that the odds of being unemployed is more likely to develop HIV treatment failure.

\section{Clinical-related factors}

Report from one study showed that lower baseline body mass index (BMI) (AOR $=2.8 ; 95 \% \mathrm{CI}: 1.01-7.5)$ [28] and patients who had height for age in the third percentile or less $(\mathrm{AHR}=3.3$; 95\% CI: 1.0-10.6) [22] were more likely to expose to HIV treatment failure. On the other hand, weight change per $1 \mathrm{~kg}$ increase $(\mathrm{AHR}=0.9,95 \% \mathrm{CI}$ : 0.9-0.9) [17], and $<50 \mathrm{~kg}$ weight at baseline (AHR $=0.58,95 \%$ CI:0.380.89) [13] were less likely to expose to HIV treatment failure.

One study showed [16], being in ambulatory functional status was at high risk (AOR $=2.9,95 \% \mathrm{CI}: 1.2-7.5)$ to develop HIV treatment failure than being in working functional status.

Another study [15] showed that those children who did not know their HIV status were at high risk (AHR = 4.4, 95\% CI: $1.8-11.3$ ) to develop HIV treatment failure.
The pooled effects of CD4 cell count $<200$ cells $/ \mathrm{mm} 3$ $(\mathrm{AOR}=7.2$; 95\% CI: $2.5-12.0), \leq 100$ cells $/ \mathrm{mm} 3(\mathrm{AOR}=$ 2.1; 95\% CI: $1.4-2.8)$ and $<50$ cells $/ \mathrm{mm} 3(\mathrm{AOR}=3.3$; 95\% CI: 1.4-5.3) as compared to those with $>200,>100$, and $>50$ cells $/ \mathrm{mm} 3$ on HIV treatment failure were estimated, respectively (Fig. 6).

The pooled effect of being on WHO clinical stage III/ IV found to be at higher risk (AOR $=1.9$; $95 \%$ CI: $1.3-$ 2.6) to HIV treatment failure as compared to stage II/I. The pooled effect of the presence of opportunistic infections (TB, diarrhea, pneumonia, other OIs) are more likely $(\mathrm{AOR}=1.8 ; 95 \% \mathrm{CI}: 1.2-2.4)$ to expose patients to HIV treatment failure (Fig. 7).

\section{Drug-related factors}

Stavudine based regimen $(\mathrm{AOR}=3.5 ; 95 \% \mathrm{CI}: 1.3-10.6)$ [28], ART drug substitution (AHR $=1.7 ; 95 \% \mathrm{CI}: 1.1-2.7)$ [22], substitution of original regimen $(\mathrm{AOR}=3.3 ; 95 \%$ $\mathrm{CI}=1.6-6.7) \quad[31]$, absence of PMTCT prophylaxis $(\mathrm{AOR}=1.4 ; 95 \% \mathrm{CI}: 1.2-2.5)$ [31], and using faith healing medicine ( $\mathrm{AOR}=8.1,95 \% \mathrm{CI}: 3.1-21.5)$ [30] were reported predictors of HIV treatment failure. Another study [30] showed that patients who didn't have consultation were positively associated (AOR $=4.9,95 \%$ CI:1.515.8) with HIV treatment failure.

The pooled effect (AOR) of poor HAART adherence to HIV treatment failure was 8.1 (95\% CI: 4.3-11.8) (Fig. 8).

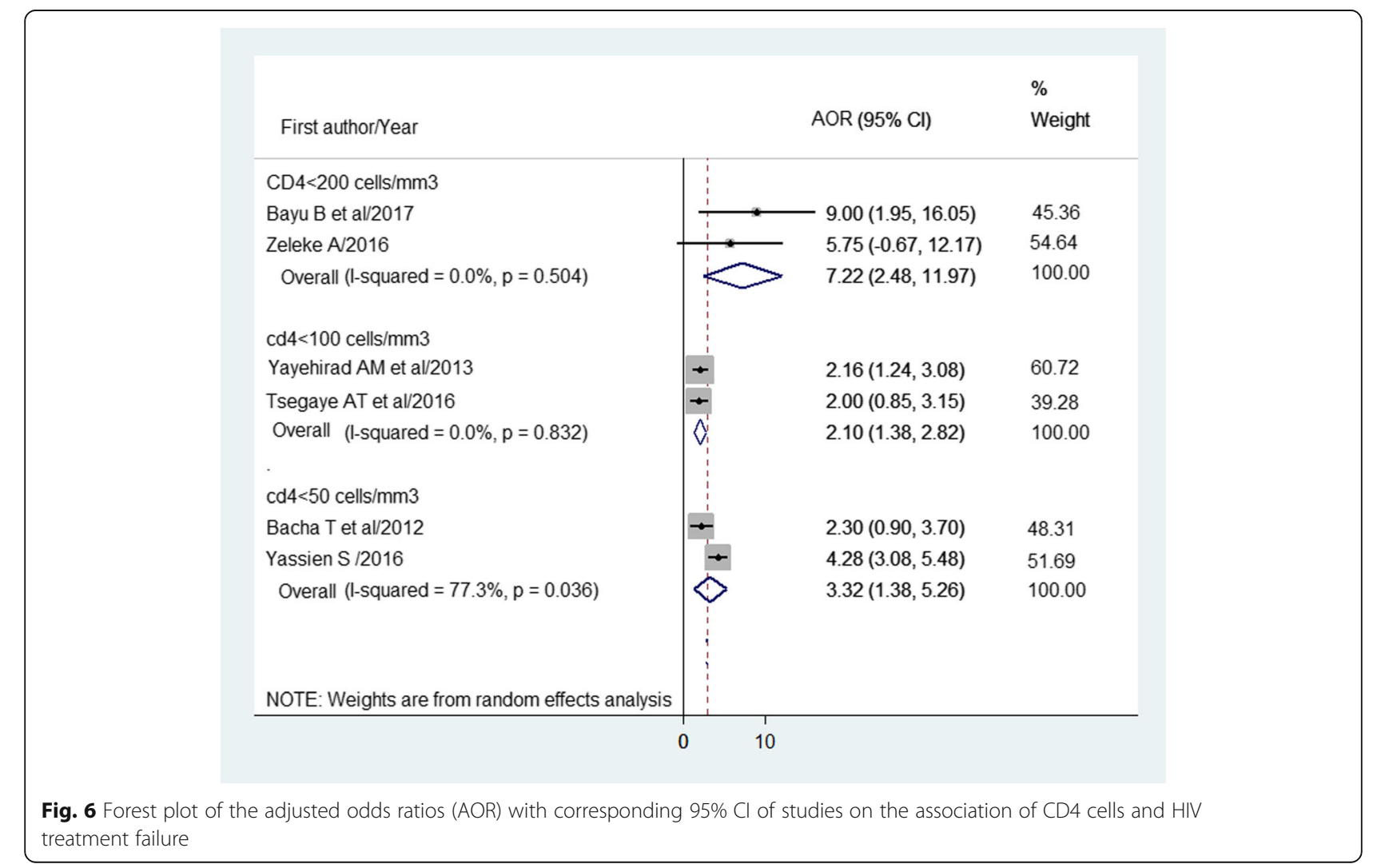




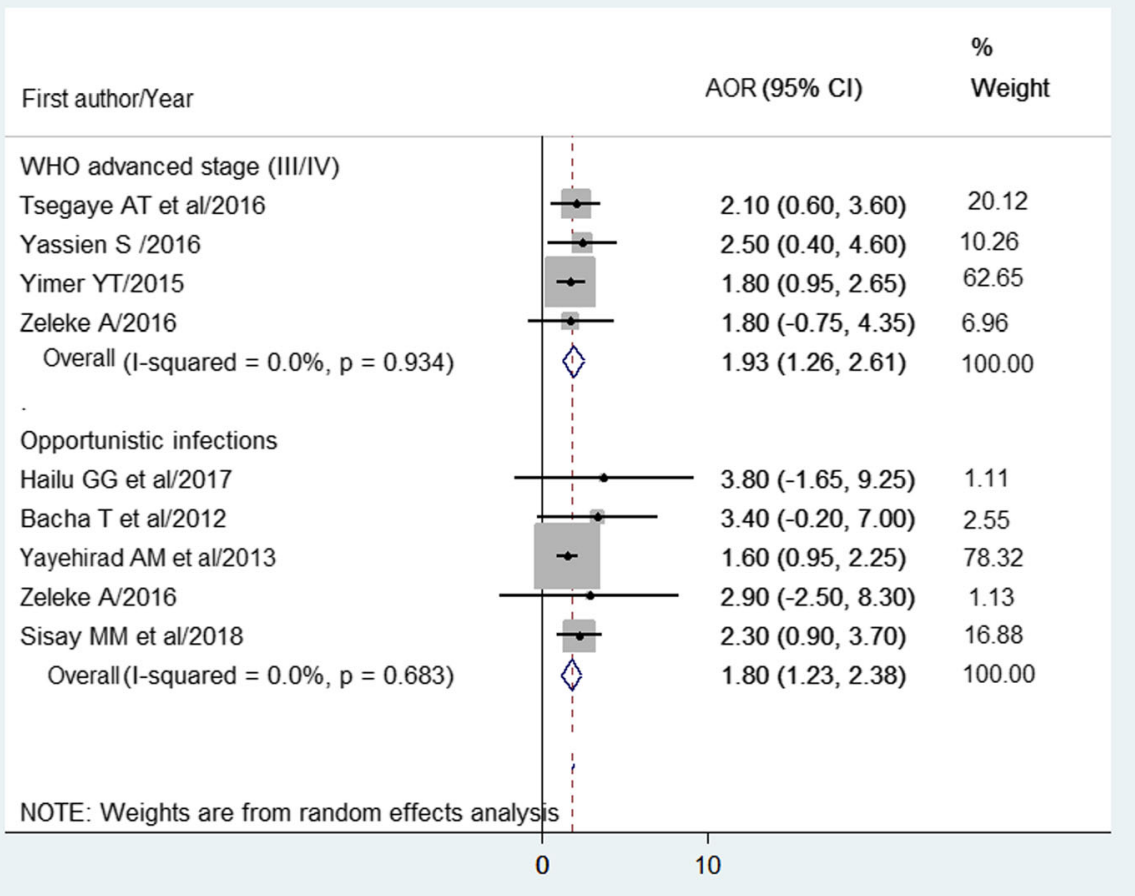

Fig. 7 Forest plot of the adjusted odds ratios (AOR) with corresponding $95 \% \mathrm{Cls}$ of studies on the association of WHO clinical stage, opportunistic infections, and HIV treatment failure

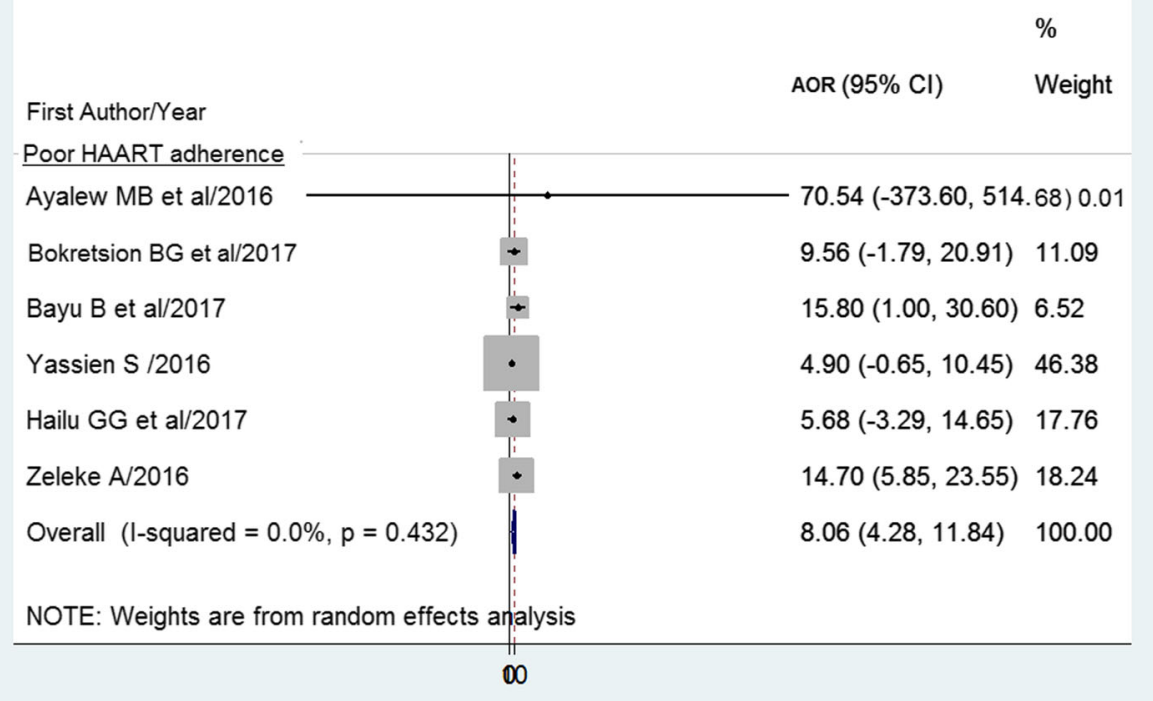

Fig. 8 Forest plot of the adjusted odds ratios with corresponding $95 \%$ Cls of studies on the association of poor HAART adherence and HIV treatment failure 


\section{Discussion}

Our study has two main findings related to the national prevalence and risk factors of HIV treatment failure. First, we noted that using the definition of HAART failure, HIV treatment failure was $15.9 \%$ (95\% CI: 11.6-20.1\%). This finding will support the global recommendation to switch patients on ART only after considering supplementary treatment failure prevention activities. In a resourcelimited country, this finding could help to keep patients longer on first-line ART regimen which preserves the more toxic and expensive second-line ART regimen.

In Ethiopia, the threat of HIV treatment failure is becoming a continuing discussion. This might be due to poor HIV care services, delayed to recognize treatment failure, [34], late initiation of HAART [33], high burden of opportunistic infections [35], lack of appropriate nutritional support [36], ART-associated adverse reaction, [37] and frequent psychological problem $[38,39]$. Besides, the absence of frequent therapeutic drug monitors and/ or resistance testing while the patient is still on the suspect or failing regimen. All four markers of lower socioeconomic status (financial hardship, non-employment, rented or unstable housing status, and non-university education) can be considered for the higher burden of HIV treatment failure in Ethiopia.

Though the WHO immunological criterion is a very low sensitivity and high specificity test [40], this finding showed that HIV treatment failure was higher (10.2\%) when the immunological definition used than that of clinical (6.3\%) and virological (5.6\%) treatment failure. This variation might be due to studies included in the immunological definition of HIV treatment failure were more than studies used to pool the clinical and virological failure. Moreover, the lower prevalence of HIV treatment failure using the clinical definition might be due to limited diagnostic capabilities. It might be difficult to identify treatment failure in patients under clinical monitoring since not all HIV care clinic sites had a systematic approach and well-trained health professionals to collect data about opportunistic infections. Therefore, using viral load based HIV treatment failure could provide better prognostic information about the risk of developing active AIDS stage which will promote more effective second-line ART. However, in most Ethiopian health institutions, virological ART failure is likely to be under-diagnosed in the routine health system and might be limited to clinical and/or immunological failure as a result. Although only five studies were included to estimate virological ART failure, the third 90 target of UNAIDS seems to be achieved. There is a plan to achieve $90 \%$ of people who are receiving ART will have viral suppression by 2020 [8].

Based on the subgroup analysis, HIV treatment failure is lower in children. ART monitoring using clinical and immunological criteria is problematic in children, and misclassification rates using the WHO pediatric guidelines remain high [41].

This review found that lower CD4 cell count, being on the WHO clinical stage III/IV, presence of opportunistic infections, and poor HAART adherence were the predominant risk factors of HIV treatment failure.

It is estimated that lower CD4 cell count and advanced WHO clinical stage leads to HIV treatment failure. Other studies $[42,43]$ reported a similar finding in other settings. The presence of opportunistic infections, on the other hand, linked to CD4 cell level. As patients' immune status becomes compromised, the rate of viral replication increases. CD4 cell count is the backbone of immunity construction that helps the human body to protect from the disease and can prevent HIV replication [44].

The presence of opportunistic infection (TB, diarrhea, pneumonia, other OIs) is more likely to exposed patients to develop HIV treatment failure. The patient gives more emphasis to the current problem than the chronic HIV, as such time interruption of taking a drug, lost followup, and other triple problems lead to HIV treatment failure.

Poor HAART adherence found to have a great impact on the occurrence of HIV treatment failure. It is widely agreed that once treatment is initiated, it should not be interrupted. In Ethiopia, within 07 days, nearly $11.3 \%$ of children have poorly adhered to ART [45]. It is expected that as duration increased the probability of ART interruptions would be more likely. The same in adult HIV patients, treatment interruption was falingl in the range between 11.8-25.8\% [46, 47]. Acquired HIV drug resistance develops when HIV mutations emerge due to viral replication in individuals on imperfect ART adherence. Poor ART adherence could lead to incomplete viral suppression and causes HIV treatment failure. Global recommendations, like on-time pill pick-up, electronic or paper-based appointment scheduling, SMS or telephone call reminders, peer counseling, cognitive behavioral therapy, and reduction of the HIV-associated stigma that prevent missing of ART drugs are not well implemented in Ethiopia.

\section{Conclusions}

HIV treatment failure in Ethiopia found to be high. Being on advanced WHO clinical stage, presence of opportunistic infections, and poor adherence to highly active antiretroviral therapy were the contributing factors of HIV treatment failure. The current finding will have health policy and clinical implications for therapeutic management decisions. Early identification of ART treatment failure allows patients to have a higher chance of success when switching to a second-line ART. A report on HIV treatment failure will be used to monitor the progress of the national action plan of 90-90-90 strategies. 


\section{Abbreviations}

AIDS: Acquired Immunodeficiency Syndrome; AOR: Adjusted Odds Ratio; Cl: Confidence Interval; HAART: Highly Active Antiretroviral; HIV: Human Immunodeficiency Virus; WHO: World Health Organization

\section{Acknowledgements}

Not applicable.

\section{Authors' contributions}

$A E$ conceived and designed the study. AE and MM established the search strategy. AE, TDH, FA, HT, DG, and MM wrote the review. All the authors read the manuscript before they have given the final approval for publication.

\section{Authors' information}

AE: Department of Pediatrics and Child Health Nursing, School of Health Sciences, College of Medicine and Health Sciences, Bahir Dar University, Bahir Dar, Ethiopia; MM: Department of Pediatrics and Child Health Nursing, School of Nursing, College of Medicine and Health Sciences, University of Gondar, Gondar, Ethiopia; DG: Department of Immunology, School of Biomedical and Laboratory Sciences, College of Medicine and Health Sciences, University of Gondar, Gondar, Ethiopia; FA: Department of comprehensive nursing, School of Nursing, College of Medicine and Health Sciences, University of Gondar, Gondar, Ethiopia; HT: Student clinic, Microbiologist, Bahirdar University, Ethiopia; TDH: Department of Epidemiology, University of Groningen, Groningen, The Netherlands.

\section{Funding}

There is no received grant from any fund agency.

\section{Availability of data and materials}

All data generated or analyzed during this study are included in this published article and its supplementary information files.

\section{Ethics approval and consent to participate}

Not applicable because no primary data were collected.

\section{Consent for publication}

Not applicable.

\section{Competing interests}

The authors declared that they have no competing interests.

\section{Author details}

${ }^{1}$ Department of Pediatrics and Child Health Nursing, School of Health Sciences, College of Medicine and Health Sciences, Bahir Dar University, P.O. Box 196, Bahir Dar, Ethiopia. ${ }^{2}$ Department of Pediatrics and Child Health Nursing, School of Nursing, College of Medicine and Health Sciences, University of Gondar, Gondar, Ethiopia. ${ }^{3}$ Department of Immunology, School of Biomedical and Laboratory Sciences, College of Medicine and Health Sciences, University of Gondar, Gondar, Ethiopia. ${ }^{4}$ Department of comprehensive nursing, School of Nursing, College of Medicine and Health Sciences, University of Gondar, Gondar, Ethiopia. ${ }^{5}$ Student Clinic, Microbiologist, Bahirdar University, Bahir Dar, Ethiopia. ${ }^{6}$ Department of Epidemiology, University of Groningen, Groningen, The Netherlands.

\section{Received: 24 October 2019 Accepted: 6 January 2020}

\section{Published online: 20 January 2020}

\section{References}

1. World Health Organization. Global Health Observatory $(\mathrm{GHO})$ data: Summary of the global HIV epidemic. 2019. https://www.who.int/gho/hiv/en/. Accessed Dec 2019.

2. UNAIDS. Country/Ethiopia Overview. 2019. https://www.unaids.org/en/ regionscountries/countries/ethiopia. Accessed Dec 2019.

3. Adal M. Systematic review on HIV situation in Addis Ababa, Ethiopia. BMC Public Health. 2019;19(1):1544.

4. Quinn TC. HIV epidemiology and the effects of antiviral therapy on longterm consequences. AIDS (London, England). 2008;22(Suppl 3):S7.

5. Hull MW, Montaner JS. HIV treatment as prevention: the key to an AIDS-free generation. J Food Drug Anal. 2013;21(4):S95-S101.
6. Granich R, Crowley S, Vitoria M, Smyth C, Kahn JG, Bennett R, et al. Highly active antiretroviral treatment as prevention of HIV transmission: review of scientific evidence and update. Curr Opin HIV AIDS. 2010;5(4):298.

7. World Health Organization. Consolidated guidelines on the use of antiretroviral drugs for treating and preventing HIV infection. Geneva: World Health Organization; 2013.

8. Sidibé M, Loures L, Samb B. The UNAIDS 90-90-90 target: a clear choice for ending AIDS and for sustainable health and development. J Int AIDS Soc. 2016;19(1):21133.

9. Levi J, Raymond A, Pozniak A, Vernazza P, Kohler P, Hill A. Can the UNAIDS 90-90-90 target be achieved? A systematic analysis of national HIV treatment cascades. BMJ Glob Health. 2016;1(2):e000010.

10. Zoungrana J et al. Prevalence and Factors Associated with Treatment Failure during Antiretroviral Therapy Atbobo-Dioulasso University Teaching Hospital (Burkina Faso) (2008-2013). Austin J HIV/AIDS Res. 2016;3(2):1027.

11. Owusu M, Mensah E, Enimil A, Mutocheluh M. Prevalence and risk factors of virological failure among children on antiretroviral therapy. BMJ Global Health. 2017;2(Suppl 2):A9-A.

12. Hawkins C, Ulenga N, Liu E, Aboud S, Mugusi F, Chalamilla G, et al. HIV virological failure and drug resistance in a cohort of Tanzanian HIV-infected adults. J Antimicrob Chemother. 2016;71(7):1966-74.

13. Yimer YT, Yalew AW. Magnitude and predictors of anti-retroviral treatment (ART) failure in private health facilities in Addis Ababa, Ethiopia. PLoS One. 2015;10(5):e0126026.

14. Hailu GG, Hagos DG, Hagos AK, Wasihun AG, Dejene TA. Virological and immunological failure of HAART and associated risk factors among adults and adolescents in the Tigray region of northern Ethiopia. PLoS One. 2018; 13(5):e0196259.

15. Sisay MM, Ayele TA, Gelaw YA, Tsegaye AT, Gelaye KA, Melak MF. Incidence and risk factors of first-line antiretroviral treatment failure among human immunodeficiency virus-infected children in Amhara regional state, Ethiopia: a retrospective follow-up study. BMJ Open. 2018;8(4):e019181.

16. Yayehirad AM, Mamo WT, Gizachew AT, Tadesse AA. Rate of immunological failure and its predictors among patients on highly active antiretroviral therapy at Debremarkos hospital, Northwest Ethiopia: a retrospective follow up study. J AIDS Clinical Res 2013;4(5).

17. Tsegaye AT, Wubshet M, Awoke T, Alene KA. Predictors of treatment failure on second-line antiretroviral therapy among adults in Northwest Ethiopia: a multicentre retrospective follow-up study. BMJ Open. 2016; 6(12):e012537.

18. Yassin S, Gebretekle GB. Magnitude and predictors of antiretroviral treatment failure among HIV-infected children in fiche and Kuyu hospitals, Oromia region, Ethiopia: a retrospective cohort study. Pharmacol Res Perspect. 2017;5(1):e00296.

19. Liberati A, Altman DG, Tetzlaff J, Mulrow C, Gøtzsche PC, loannidis JP, et al. The PRISMA statement for reporting systematic reviews and meta-analyses of studies that evaluate health care interventions: explanation and elaboration. PLoS Med. 2009;6(7):e1000100.

20. Wells GA, Shea, B., O'Connell, D., Peterson, J., Welch, V., et al,. The NewcastleOttawa scale (NOS) for assessing the quality of nonrandomized studies in meta-analysis 2011.

21. Teshome W, Assefa A. Predictors of immunological failure of antiretroviral therapy among HIV infected patients in Ethiopia: a matched case-control study. PLoS One. 2014;9(12):e115125.

22. Bacha T, Tilahun B, Worku A. Predictors of treatment failure and time to detection and switching in HIV-infected Ethiopian children receiving first line anti-retroviral therapy. BMC Infect Dis. 2012;12(1):197.

23. Sisay $C$, Bekele A, Sisay A, Mekonen H, Terfa K. Incidence and predictors of anti-retroviral treatment (ART) failure among adults receiving HIV Care at Zewditu Memorial Hospital, Addis Ababa, Ethiopia. J AIDS Clin Res. 2017; 8(749):2.

24. Getnet $Y$. Determinants of first line antiretroviral treatment failure in public hospitals of Addis Ababa, Ethiopia: unmatched case control study. J Biol Agriculture Healthcare. 2014;4(224-3208):1-12.

25. Abdissa A, Yilma D, Fonager J, Audelin AM, Christensen LH, Olsen MF, et al. Drug resistance in HIV patients with virological failure or slow virological response to antiretroviral therapy in Ethiopia. BMC Infect Dis. 2014;14(1):181.

26. Workneh N, Girma T, Woldie M. Immunologic and clinical outcomes of children on HAART: a Retrospective cohort analysis at Jimma University specialized hospital. Ethiop J Health Sci. 2009;19(2). 
27. Tadesse BT, Foster BA, Jerene D, Ruff A. Cohort profile: improving treatment of HIV-infected Ethiopian children through better detection of treatment failure in southern Ethiopia. BMJ Open. 2017;7(2):e013528.

28. Babo YD, Alemie GA, Fentaye FW. Predictors of first-line antiretroviral therapy failure amongst HIV-infected adult clients at Woldia hospital. Northeast Ethiopia PloS one. 2017;12(11):e0187694.

29. Bayu B, Tariku A, Bulti AB, Habitu YA, Derso T, Teshome DF. Determinants of virological failure among patients on highly active antiretroviral therapy in University of Gondar Referral Hospital, Northwest Ethiopia: a case-control study. HIV/AIDS (Auckland, NZ). 2017;9:153-9.

30. Bokretsion GB, Endalkachew N, Getachew KA. HIV/AIDS treatment failure and its determinant factors among first line HAART patients at Felege-Hiwot Referral Hospital, Bahir Dar, Northwest Ethiopia. J AIDS Clin Res. 2017;8(11):2-8.

31. Zeleke A. Prevalence of antiretroviral treatment failure and associated factors in HIV infected children on antiretroviral therapy at Gondar University hospital, retrospective cohort study. Int J Med Med Sci. 2016;8(11):125-32.

32. Ayalew MB, Kumilachew D, Belay A, Getu S, Teju D, Endale D, et al. First-line antiretroviral treatment failure and associated factors in HIV patients at the University of Gondar Teaching Hospital, Gondar, Northwest Ethiopia. HIV/ AIDS (Auckland, NZ). 2016;8:141.

33. Nash D, Tymejczyk O, Gadisa T, Kulkarni SG, Hoffman S, Yigzaw M, et al. Factors associated with initiation of antiretroviral therapy in the advanced stages of HIV infection in six Ethiopian HIV clinics, 2012 to 2013. J Int AIDS Soc. 2016;19(1):20637.

34. Deribew A, Biadgilign S, Berhanu D, Defar A, Deribe K, Tekle E, et al. Capacity of health facilities for diagnosis and treatment of HIV/AIDS in Ethiopia. BMC Health Serv Res. 2018;18(1):535.

35. Haileamlak A, Hagos T, Abebe W, Abraham L, Asefa H, Teklu AM. Predictors of hospitalization among children on ART in Ethiopia: a cohort study. Ethiop J Health Sci. 2017;27(1):53-62.

36. Gebremichael DY, Hadush KT, Kebede EM, Zegeye RT. Food insecurity, nutritional status, and factors associated with malnutrition among people living with HIV/AIDS attending antiretroviral therapy at public health facilities in west Shewa zone, Central Ethiopia. Biomed Res Int. 2018;2018.

37. Abdissa S, Fekade D, Feleke Y, Seboxa T, Diro E. Adverse drug reactions associated with antiretroviral treatment among adult Ethiopian patients in a tertiary hospital. Ethiop Med J. 2012;50(2):107-13.

38. Selamawit Z, Nurilign A. Common mental disorder among HIV infected individuals at Comprehensive HIV Care and Treatment Clinic of Debre Markos referral Hospital, Ethiopia. J AIDS Clin Res. 2015;6(2).

39. Amare T, Getinet W, Shumet S, Asrat B. Prevalence and associated factors of depression among PLHIV in Ethiopia: systematic review and meta-analysis, 2017. AIDS Res Treatment. 2018;2018.

40. Le NK, Riggi E, Marrone G, Van Vu T, Izurieta RO, Nguyen CKT, et al. Assessment of WHO criteria for identifying ART treatment failure in Vietnam from 2007 to 2011. PLoS One. 2017;12(9):e0182688.

41. Westley BP, DeLong AK, Tray CS, Sophearin D, Dufort EM, Nerrienet E, et al. Prediction of treatment failure using 2010 World Health Organization guidelines is associated with high misclassification rates and drug resistance among HIV-infected Cambodian children. Clin Infect Dis. 2012:55(3):432-40.

42. Khienprasit N, Chaiwarith R, Sirisanthana T, Supparatpinyo K. Incidence and risk factors of antiretroviral treatment failure in treatment-naïve HIV-infected patients at Chiang Mai University Hospital, Thailand. AIDS Res Ther. 2011;8(1):42.

43. Soria A, Porten K, Fampou-Toundji J, Galli L, Mougnutou R, Buard V, et al. Resistance profiles after different periods of exposure to a first-line antiretroviral regimen in a Cameroonian cohort of HIV type-1-infected patients. Antivir Ther. 2009;14(3):339-47.

44. Okoye AA, Picker L. CD 4+ T-cell depletion in HIV infection: mechanisms of immunological failure. Immunol Rev. 2013;254(1):54-64.

45. Endalamaw A, Tezera N, Eshetie S, Ambachew S, Habtewold TD. Adherence to highly active antiretroviral therapy among children in Ethiopia: a systematic review and meta-analysis. AIDS Behav. 2018;22(8):2513-23.

46. Giday A, Shiferaw W. Factors affecting adherence of antiretroviral treatment among AIDS patients in an Ethiopian tertiary university teaching hospital. Ethiop Med J. 2010;48(3):187-94.

47. Markos E, Worku A, Davey G. Adherence to ART in PLWHA and Yirgalem hospital, South Ethiopia. Ethiop J Health Dev. 2008;22(2):174-9.

\section{Publisher's Note}

Springer Nature remains neutral with regard to jurisdictional claims in published maps and institutional affiliations.

Ready to submit your research? Choose BMC and benefit from:

- fast, convenient online submission

- thorough peer review by experienced researchers in your field

- rapid publication on acceptance

- support for research data, including large and complex data types

- gold Open Access which fosters wider collaboration and increased citations

- maximum visibility for your research: over $100 \mathrm{M}$ website views per year

At BMC, research is always in progress.

Learn more biomedcentral.com/submissions 